\title{
EUROPEAN EXPERIENCES AND CROATIAN PERSPECTIVES OF COMPENSATION PROGRAMS IN CASE OF CHILDHOOD VACCINE INJURY
}

\author{
Barbara Preložnjak * \\ Ivan Šimović ${ }^{* *}$
}
„The feebleness of infancy demands a continual protection. Everything must be done for an imperfect being, which as yet does nothing for itself."

Jeremy Bentham, Theory of Legislation (1840)

\begin{abstract}
Health is considered a basic human right without which it is impossible to achieve life ends. Efficient and justly exercise of the right to health is one of the most important tasks of modern societies. Childhood vaccination is one of the health care measures that aim to protect health although in rare cases it may cause long-term health problems. In this paper, we attempt to present the role of justice in the protection of children's health in cases of its impairment caused by vaccines. The paper will express the view that no-fault compensation system serves to social justice goals in protection of the most vulnerable members of society and at the same time discourage long and expensive litigation's.
\end{abstract}

KEYWORDS: childhood vaccine injury, justice, vaccines, compensation programs, liability

Assistant Professor, Department for Legal Theory, Faculty of Law, University of Zagreb; barbara.preloznjak@pravo.hr.

** Assistant Professor, Department for Family Law, Faculty of Law, University of Zagreb; isimovic@pravo.hr. 


\section{INTRODUCTION}

Health is vital for every human being as without health it is not possible to obtain a state of complete physical, mental and social well-being. ${ }^{1}$ Children are vulnerable young human beings and they are more at risk to illness and health complications. ${ }^{2}$ If children are spared from disease, they can grow into healthy adults, perceive their ends and contribute to the development of society. ${ }^{3}$ Therefore, children require extra attention in order to enjoy the best possible health. One of the measures to suppress diseases is considered to be the vaccination. ${ }^{4}$ Medical experts claim that compulsory vaccination plays an important role in preventing the spread of childhood infectious diseases in community. ${ }^{5}$ Although vaccines lead to a significant reduction in the disease risk, they may, like any other medical product, cause side effects. ${ }^{6}$ Most side effects, as medical experts claim, are mild but vaccines can also cause serious side effects and trigger long-term health problems that are an obstacle to highest standards of health. ${ }^{7}$ However, long-term health problems cannot be cured, so children are not able to pursue their best possible ends and highest standards of health are no more attainable.

In modern European states governments care for those who contributed to public health and suffered health impairment. Those states have a good practice of no-fault compensation programs under which children can get compensation outside the civil litigation as the unfortunate victims of adverse reactions to vaccines. However, in Croatia victims of vaccine injuries bear burden of health

\footnotetext{
1 Constitution of World Health Organisation as adopted by the International Health Conference, New York, 19 June - 22 July 1946; signed on 22 July 1946 by the representatives of 61 States (Official Records of WHO, no. 2, p. 100) and entered into force on 7 April 1948.

2 Understanding Children's Right to Health, https://www.humanium.org/en/fundamental-rights-2/health/, accessed on 18/01/2018.

3 Ibid.; Similarly Alinčić, M., Hrabar, D., Jakovac-Lozić, D., Korać Graovac, A.: Obiteljsko pravo, Zagreb, 2007, p. 228.

4 Understanding Children's Right to Health, https://www.humanium.org/en/fundamental-rights-2/health/, accessed on 18/01/2018.; Similarly Alinčić et al., op. cit. (fn. 3), p. 244.

5 Dornbusch, H.J., Hadjipanayis, A., del Torso, S. et al.: We strongly support childhood immunization-statement from the European Academy of Pediatrics (EAP), European Journal of Pediatrics, 176 (5), pp. 679-680.; Fine, P., Eames, K., Heymann, D. L.: Herd Immunity: A Rough Guide, Clinical Infectious Diseases, 52 (7), 2011, pp. 911-916.

6 Vaccine Side Effects and Adverse Events, https://www.historyofvaccines.org/content/articles/vaccine-side-effects-and-adverse-events,accessed on 12/01/2018.

7 Jefferson, T.: Vaccination and its adverse effects: real or perceived. Society should think about means of linking exposure to potential long-term effect, British Medical Journal, 317 (7152), 1998, pp 159-160.
} 
impairment by themselves. In other words, if victims of vaccine injury want to be compensated for health impairment they have to rely on civil litigation.

If we assume that vaccination contributes to public health as it provides collective immunity from communicable childhood diseases, the question is whether it is just that the victims of vaccine injuries in Croatia seek compensation through long and expensive judicial process or the government should provide them compensation outside the litigation. In order to answer that question, the authors will examine the notion of justice on examples of selected European no-fault compensation programs and Croatian example of compensation claimed by a court.

\section{ROLE OF JUSTICE IN CASE OF VACCINE HEALTH IMPAIRMENT}

Children do not have the capacity to protect themselves or make prudent choices regarding health risks. ${ }^{8}$ Therefore, the health of children is dependent on the decisions of others and on features of the social structure over which children have no control of. ${ }^{9}$ While promotion of children's health can be considered as one of the parental responsibilities, sometimes it may be difficult for parents to protect children's health if risks and health choices are paramount within the society where they live. ${ }^{10}$ We may consider an example of routine childhood vaccination. Vaccination is one of health care measures, which aims specifically at protecting and promoting the health of children and as well the public health. ${ }^{11}$ Although vaccines can contribute to human health, in some cases they can impose serious long-term health problems. In such cases, it would be wrong to put the burden of responsibility for children's health solely on the parents as their legal guardians. ${ }^{12}$ As vaccines protect children's health, they also have positive effect to society, as they are contributing to public health by ensuring strong collective immunity against diseases. Therefore, the burden

\footnotetext{
8 Verweij, M., Dawson, A.: Children's Health, Public Health, Public Health Ethics, 4 (2), 2011, p. 107.; Hrabar, D., Prava djece u porodičnim odnosima, Doctoral dissertation, Faculty of Law, Unversity of Zagreb, 1991, p. 96.

9 Public Health Ethics, https://plato.stanford.edu/entries/publichealth-ethics/\#Pat, accessed on 18/03/2018.; Hrabar, D.: Prava djece u obiteljskom zakonodavstvu, in Hrabar, D. (ed.), Prava djece-multidisciplinarni pristup, Zagreb, 2016, p. 65.

10 Hrabar, D.: Pravni status djeteta kao pacijenta, Dijete i društvo, 4 (3-4), 2009, pp. 402403.; Verweij; Dawson, op. cit. (fn. 8), p. 107.

11 Verweij, M.; Dawson, A., Ethical principles for collective immunization programmes, Vaccine, 22 (23-24), pp. 3122-3126.

12 Verweij; Dawson, op. cit. (fn. 8), p. 107.
} 
of responsibility for children's health should be divided between parents and the government that prescribed the obligation to vaccinate. The government should support parents to raise their children in a way that gives them the best chance of a flourishing life. If children's health is compromised by vaccination, it will certainly have negative effects on their well-being and disarrange their life plans. As social justice concerns "about well-being and about outcomes" it puts before the government the task to ensure that citizens have a sufficient amount of health as one of dimensions of well-being. ${ }^{13}$ From that standpoint, children's health should be considered as matters of justice if vaccine health impairment occurs during a stage of life in which major life plans are affected and the pain and suffering is great enough that it undermines those life plans. ${ }^{14}$ Therefore, governments that want to be considered as just should take care of "fair, equitable, and appropriate distribution of benefits, burdens and costs" of vaccination in order to promote and preserve well-being of its citizens. ${ }^{15}$ In case of childhood vaccination it means that governments should have in mind that distribution of public health benefits that medicine assigns to vaccines have to be proportionate to risks of unwanted side effects of vaccines that are usually unpredictable. In other words, if side effects of vaccination occur, the affected children should not bear a burden of health impairment by themselves. Therefore, in case of vaccine health impairment the government should give at least some priority to the worst off, or in our case, to children whose medical conditions make them among the worst off. ${ }^{16}$ The moral reason why governments should be concerned for children who are worse off as consequence of vaccine side effects lies in the fact that their disadvantages are undeserved. ${ }^{17}$ Children don't deserve loss of health and with it loos of range of capabilities and opportunities, as vaccines are supposed to enhance their health and to protect community health, as well. Thus, justification for giving children the opportunity for compensation from society rests on social commitments to what Rawls calls a "Difference Principle". ${ }^{18}$ According to the "Difference Principle", basic social and economic institutions of society should be arranged to maximize the expectations of the worst off representa-

13 Powers, M., Faden, R.: Social Justice, New York, 2006, p. 82.

14 See Daniels, N.: Just Health Care, Cambridge, 1985, p. 28; Powers, Faden., op. cit. (fn. 13), p. 36.

15 Beauchamp, T. L., Childress, J. F., Principles of Biomedical Ethics, Oxford, 2001, p. 226.

16 Powers, Faden, op. cit. (fn. 13), p. 171.

17 Brock, D., W.: Priority to the Worst Off in Health-Care Resource Prioritization, in Rhodes,

R.; Battin, M. and Silvers, A. (eds.), Medicine and Social Justice, New York, 2002, p. 362.

18 Rawls, J., A Theory of Justice, Cambridge, 1999, pp. 65-70. 
tive group in other to preserve fair equality of opportunity. ${ }^{19}$ This means that governments should have an obligation to provide institutions, such as public or private vaccine compensation funds, that protect opportunity range and eliminate those undeserved life disadvantages. ${ }^{20}$ In case when the government doesn't compensate for the damage done to children on account of vaccination, society unjustly enjoys the benefits of the collective immunity at the expense of children who have been injured by the vaccine. ${ }^{21}$ Such government would be inconsistent with Rawls' understanding of fair cooperation in which benefits and burdens have to be distributed justly. ${ }^{22}$ Therefore, justice in case of vaccine health impairment should "require obligations" for government to remedy existing health disadvantages that undermine the prospects for well-being by designing social institutions which will prevent such disadvantage from arising. ${ }^{23}$

\section{NO-FAULT COMPENSATION PROGRAMS AND VACCINE HEALTH IMPAIRMENT}

In Europe, childhood vaccination is a proven tool for controlling and eliminating life-threatening infectious diseases. ${ }^{24}$ All European countries have a vaccination schedule, recommending the vaccines to be given at various ages during childhood. ${ }^{25}$ Due to good vaccination policy certain diseases have already been eradicated, while others are hoped to be eliminated soon, such as measles and congenital rubella. ${ }^{26}$ Although the benefits of childhood vaccination are clear, some children occasionally suffer from vaccine-related adverse events and bear a significant burden for the vaccine benefit provided to the society. According to principles of fairness and solidarity modern societies accepted belief that governments have a special responsibility to those injured by properly manufactured and administered vaccines used in public health

\footnotetext{
19 Ibid.

20 Daniels, N.: Justice, Health, and Health care, in Rhodes, R., Battin, M., Silvers, A. (eds.), Medicine and social justice, New York, 2002, p. 9.

21 Similarly Tucak, I.: Legal and Ethical Justification of Compensation Regarding Compulsory Vaccination, Law and Politics, 15 (2), 2017, p. 152.

22 Rawls, J., op. cit. (fn. 18), p. 4.

23 See also Powers; Faden, op. cit. (fn. 13), p. 72.

24 Campaign essentials for World Immunization Week 2018, http://www.who.int/campaigns/ immunization-week/2018/campaign-essentials/en/, accessed on 21/03/2018.

25 Childhood immunisation, https://ec.europa.eu/health/vaccination/childhood_immunisation_en, accessed on 06/06/2018.

26 Vaccine-preventable diseases, https://ecdc.europa.eu/en/immunisation-vaccines/facts/vaccine-preventable-diseases, accessed on 06/06/2018.
} 
programs. ${ }^{27}$ In Europe, a dozen countries provide some form of compensation for injuries following vaccination that are mostly administratively managed through the national government. ${ }^{28}$ The first vaccine compensation program was implemented in 1961, after the German Supreme Court ruled that people who were injured by compulsory smallpox vaccination were entitled to compensation. ${ }^{29}$ After Germany, a similar program was implemented in 1963 in France. ${ }^{30}$ Concern over injuries caused by medicines and the inadequacies of traditional litigation processes in the 1960s resulted with raising awareness of the necessity of establishing a vaccine compensation programs. Thus, in the 1970s, concerns over adverse events related to diphtheria-tetanus-pertussis vaccination resulted with establishing compensation program in several European countries such as Austria, Denmark, Sweden and the United Kingdom of Great Britain and Northern Ireland. ${ }^{31}$ In the 1980s, compensation programs were implemented in Finland and in 1990s in Italy and Norway. ${ }^{32}$ In the 2000s, compensation programs were implemented in Hungary and Slovenia. ${ }^{33}$

Although the various statutory structures reflect differing legal, social, and cultural settings of vaccine compensation programs, these programs embody a general commitment to provide special assistance to children who have suffered adverse reactions to vaccination. Due to the spatial limitation of this article, in the following sub-headings we will focus on the German, Italian and Slovenian program, which we chose because of the closeness of their legal tradition to Croatian legal tradition. Moreover, selected vaccine compensation

27 Mello, M. M.: Rationalizing Vaccine Injury Compensation, Bioethics, 22 (1), 2008, pp. $32-42$.

28 Looker, C., Kelly, H.: No-fault compensation following adverse events attributed to vaccination: a review of international programmes, Bulletin of the World Health Organization, 89 (5), pp. 371-372; Evans, G.: Vaccine injury compensation programs worldwide, Vaccine, 17 (3), 1999, p. S27.

29 Hohmann, A., Hollmann, K., Tempel, G., Wunderle, W.: 10 jahre Infektionsschutzgesetz Meldepflichtige Infektionskrankheiten in Bremen 2001-2011, Bremen, p. 8.

30 Dispositif de règlement amiable des dommages imputables à des vaccinations obligatoires, Office National d'Indemnisation des Accidents Médicaux, Paris, 2004, http://www. oniam.fr/vaccinations.php, accessed on 21/03/2018.

31 Lasagna, L.: The Chilling Effect of Product Liability on New Drug Development, in Huber, P., W., Litan, R., E. (eds.), The Liability Maze: The Impact of Liability Law on Safety and Innovation, Washington, 1991, pp. 348, 353.

32 Ibid, 348.; Salmon, D. A., Teret, S.P., MacIntyre, C. R., Salisbury, D., Burgess, M. A., Halsey, N. A.: Compulsory vaccination and conscientious or philosophical exemptions: past, present, and future, The Lancet, 367 (9508), 2006, pp. 436-442.; Tucak, op. cit. (fn. 21), p. 147.

33 See Looker, Kelly, op. cit. (fn. 28), pp. 371-372; Tucak, op. cit. (fn. 21), p. 152.; Boncz, I., Sebestyén, A., Compensation for vaccine injury in Hungary, The Lancet, 367 (9517), 2006, p. 1144. 
programs operate on similar premises (e.g. administration and funding, eligibility, process and decision-making, standard of proof, elements of compensation and litigation rights) that will be analyzed in further sub-headings.

\subsection{GERMANY}

In Germany, childhood vaccinations are recommended by the health authorities of the federal states (Länder) and are based on the Standing Committee on Vaccination (hereinafter: STIKO) recommendations according to $§ 20$ (3) of the Protection against Infection Act. ${ }^{34}$ According to $\S 60$ IfSG a special compensation program is established under social security law to compensate health impairment due to vaccination damage. Vaccination damage is defined under $\S 2$ no. 11 IfSG as the health-related and economic consequences of damage to health that exceed the normal reaction to a vaccination. However, a vaccine compensation in terms of $\S 60$ IfSG applies only if the vaccination had been publicly recommended. In other words, it is required that recommendation confirms public interest in the vaccination, as vaccines do not only serve purpose of protecting the individual, but also the public good of avoiding the spread of diseases. ${ }^{35}$ In order to receive compensation, the claimant must prove that the vaccination caused an unusual reaction, and that reaction caused adverse consequences. ${ }^{36}$ The vaccination as such, the reaction and the adverse consequences must be proven and the claimant must demonstrate reasonable likelihood of causation between them ${ }^{37}$ In order to decide whether the health impairment is compensable, the court will also consider the state of scientific knowledge at the time of decision. ${ }^{38}$ When the court decides to compensate for

\footnotetext{
34 Statement of the German Standing Committee on Vaccination at the RKI Recommendations of the Standing Committee on Vaccination (STIKO) at the Robert Koch Institute/ Effective: August 2015, Epidemiologisches Bulletin, No. 34, 2015, pp. 327-362.; Protection against Infection Act (Gesetz zur Verhütung und Bekämpfung von Infektionskrankheiten beim Menschen (Infektionsschutzgesetz)) from 2000. (in version from 17th July 2017, BGBl. I S. 2615; hereinafter: IfSG).

35 Ritz, H.G.: Impfentschädigung, in Deinert, O., Welti, F. (eds.), Stichwortkommentar Behindertenrecht, Baden-Baden, 2014, margin n. 1.; Rajneri, E., Borghetti, J. S., Fairgrieve, D., Rott, P.: Remedies for Damage Caused by Vaccines: A Comparative Study of Four European Legal Systems, European Review of Private Law, 26 (1), 2018., p. 75.

36 Rajneri; Borghetti; Fairgrieve; Rott, op. cit. (fn. 35), p 75.

37 § 61 IfSG.

38 According to the Federal Social Court (Bundessozialgericht; hereinafter: BSG) the causal link is present if under consideration of the leading medical opinion it is more likely than not that the vaccination was the cause of the permanent damage. See: Rajneri; Borghetti; Fairgrieve; Rott, op. cit. (fn. 35), p 75.
} 
the health impairment caused by publicly recommended vaccinations, compensation is assured by the federal states. ${ }^{39}$ As a form of compensation, claimant can obtain, for example, the medical treatment, sickness benefits, rehabilitation measures, an economic rent or compensation for the inability to exercise life ends. ${ }^{40}$ Parallel to the compensation program under social security law, reimbursement in cases of vaccine health impairment is available through special liability regime that is complemented by regular tort law. ${ }^{41}$

\subsection{ITALY}

Italian vaccine compensation program was set up because of a large number of cases that were brought to the court under the Law $\mathrm{N}^{\circ} 210 / 92 .{ }^{42}$ Program was firstly reserved for compensation of health impairment caused by the compulsory vaccines. ${ }^{43}$ Following the intervention of the Italian Constitutional Court, the program started to compensate health impairment in cases where vaccination was not compulsory, but was merely recommended by the Government. ${ }^{44}$ To apply for compensation, request should be submitted to the Minister of Health within the peremptory time limit of three years since the claimant became aware of the health impairment. ${ }^{45}$ In order to be entitled for the compensation, the claimant has the burden of proving causation. ${ }^{46}$ According to Article 4(1) of Law $\mathrm{N}^{\circ} 210 / 92$ causal link between the vaccination and the impairment of psycho-physical integrity is expressed by the commission of medical experts. Pursuant to Article 5(1) of the same Law claimant has the right to appeal to Minister of Health if he is not satisfied with the commission's decision. The redress provided by the vaccine compensation program is reimbursed from state budget and is usually lower than full compensation that could be received for health impairment. ${ }^{47}$ Therefore, the claimant can

\footnotetext{
39 Evans, op. cit. (fn. 28), p. S26.

$40 § 60$ IfSG.

41 Rajneri, Borghetti, Fairgrieve, Rott, op. cit. (fn. 35), p 79.

42 Compensation of infringement of irreversible types of outcomes of compulsory vaccination, and transfusion (Decreto Legislativo n. 210 del 25/2/1992, Indennizzo a favore dei soggetti danneggiati da complicanze di tipo irreversibile a causa di vaccinazioni obbligatorie, trasfusioni, G.U. 210/1992; hereinafter: Law N²10/92).

43 Rajneri, Borghetti, Fairgrieve, Rott, op. cit. (fn. 35), p 60.

44 Caranta, R., Danni da vaccinazione e responsabilità dello Stato, Responsibilità Civile e Previdenz, 63 (1), 1998, p. 1352.

45 Art. 2, para 1 Law $\mathrm{N}^{\circ} 210 / 92$.

46 Rajneri, Borghetti, Fairgrieve, Rott, op. cit. (fn. 35), p 60.

47 Art. 5, para 3 Law N²10/92.; Art. 8 Law N²10/92.
} 
seek justice for health impairment before court in the period of one year since the decision on appeal regarding compensation was adopted. ${ }^{48}$ The statutory provisions on proving causation in court procedures are very limited and they are prescribed by Criminal and Civil Code. ${ }^{49}$ If compensation is requested for health impairment that has elements of criminal infringement, the proof of causation has to reach a degree of certainty. ${ }^{50}$ In cases, which have elements of civil infringement, it is sufficient that claimant proves that the causal link between vaccination and health impairment is the most probable one. ${ }^{51}$ In order to adjudicate compensation, the judge, besides the evaluation of causation, is also allowed to interpret the purpose of the applicable laws as well to take into consideration the scientific rules. ${ }^{52}$ When the court decides to compensate for the health impairment caused by publicly recommended vaccines, compensation is assured from national treasury. ${ }^{53}$ As a form of compensation, the child as a claimant can obtain, for example, free medical care, medication and disability pension. ${ }^{54}$

\subsection{SLOVENIA}

In Europe, Slovenia has one of the most aggressive and comprehensive vaccination programs. ${ }^{55}$ Its program is mandatory for nine designated diseases. ${ }^{56}$ As

\footnotetext{
48 Art. 5, para 3 Law N²10/92.

49 Art 41, 42 Criminal Code (Codice penale from 19th October 1930 (in version of 11th January 2018, G.U. 4/2018; hereinafter: CP); Art 1223 Civil Code (Codice civile from 4th April 1942 (in version of 11th January 2018, G.U. 4/2018; hereinafter: CC).

50 Rajneri, Borghetti, Fairgrieve, Rott, op. cit. (fn. 35), p 61.

51 Ibid.

52 Bona, M.: Causalità materiale, causalità scientifica e causalità giuridica a confronto: quale ruolo ai consulenti tecnici nell'accertamento del nesso di causa?, in Bona, M. et al. (eds), Il nesso di causa nel danno alla persona, Milano, 2005, p $147 \mathrm{ff}$.

53 Evans, op. cit. (fn. 28), p. S26.

54 Ibid.

55 Walkinshaw, E.: Mandatory vaccinations: The international landscape, CMAJ, 183 (16), 2011, p. E1168.; Kraljić, S., Slovenija spada med države s strogo ureditvijo, 2018, https://www. vecer.com/slovenija-spada-med-drzave-s-strogo-ureditvijo-6382626, accessed on 07/06/2018.

56 Walkinshaw, E.: Mandatory vaccinations: The international landscape, CMAJ, 183 (16), 2011, p. 1168.; Kraljić, S.: Obvezno cepljenje v Sloveniji: razkorak med pravom in vsakdanjo prakso? Mandatory vaccination in Slovenia: the gap between law and everday practise?, in Kraljić,, S., Reberšek Gorišek, J., Rijavec, V. (eds.), 27. Posvetovanje Medicina, pravo in družba, (23- 24.3. 2018, Maribor, Slovenija), Sodobni izzivi in dileme : konferenčni zbornik, Maribor, 2018, p. 122, 125. pp. 122-135.; Lukšić, K.: Pravica ali dolžnost staršev, da odločaju o cepljenju svojih otrok, magistrsko delo, Maribor, 2016, p. 32.
} 
in Italy, the Slovenian Constitutional Court (hereinafter: SCC) played a major role in forming a compensation program for vaccine injuries by requiring proper regulation of the state liability. ${ }^{57}$ In 2004 SCC declared the Act against infectious diseases unconstitutional as it did not regulate justified reasons for waiving mandatory vaccination and adequate arrangements of liability for damage due to the side effects of vaccination. ${ }^{58}$ The SCC in its judgment declared that vaccination, as each medical intervention, is associated with certain risks, and hence the legislator is obliged to provide the appropriate remedy for victims of vaccine injuries. ${ }^{59}$ According to SCC remedies should be based on the principle of solidarity, which requires the government to compensate for vaccine injuries. ${ }^{60}$ In this regard, the SCC considers that it is unacceptable that an individual suffers from the damage caused by a mandatory vaccination that is considered to benefit public health. ${ }^{61}$

Since 2006 responsibility for injury caused by mandatory vaccination is regulated by new Act on Infectious Diseases. ${ }^{62}$ According to Article 53a(1) of the Infectious Diseases Act individual whose health is impaired by compulsory vaccination, as evidenced by serious and lasting reduction of vital functions, is entitled to seek compensation from the state. ${ }^{63}$ Health impairment in this context does not include damage caused by incorrect administration of the vaccine or from the inadequate quality of the vaccine as specified by the Slovenian regulations governing medicines. ${ }^{64}$ In order to be entitled for compensation, the claimant has to prove causational link between health impairment and vaccination, which is evaluated by the minister responsible for health based on the expert opinions. ${ }^{65}$ As a form of compensation, the child as a claimant

\footnotetext{
57 Tucak, op. cit. (fn. 21), p. 152.

58 Constitutional Court Decision of Republic of Slovenia (Odločba o ugotovitvi, da prva alineja prvega odstavka 22. člena, 4. točka prvega odstavka 57. člena in drugi odstavek 57. člena Zakona o nalezljivih boleznih niso v neskladju z Ustavo, in o ugotovitvi neskladnosti Zakona o nalezljivih boleznih z Ustavo, stran 2906, U-I-127/01), Uradni list RS 25/2004., https:// www.uradni-list.si/glasilo-uradni-list-rs/vsebina/2004-01-1089/, accessed on 06/06/2018.

59 Ibid.

60 Ibid.; See also: Kompare, N.: Obvezno cepljenje otrok proti nalezljivim boleznim, Pravna praksa, 10, 2015, pp. 17-18.

61 Ibid.

62 Infectious Diseases Act (Zakon o nalezljivih boleznih, Uradni list RD 33/06- officially purified text; hereinafter: IDA).

63 Art. 53. f. IDA.; See Možina, D.: Odškodninska odgovornost države, Pravni letopis, 2013, pp. 161-162.

64 Art. 53. a. para 3 IDA.

65 Art. 53. d. para 1 IDA
} 
can obtain monetary compensation paid from the state budget. ${ }^{66}$ The amount of compensation in case of health impairment is approximately 60.000 euros and is valued once a year by the ministry responsible for health, in accordance with the data of the Statistical Office of the Republic of Slovenia on the level of annual inflation. ${ }^{67}$ In cases when health impairment is a result of improper handling with the vaccine by medical personnel or result of inadequate quality of the vaccine, claimant has the opportunity to seek compensation through court procedure against the manufacturer of the vaccine. ${ }^{68}$

\section{CHILDHOOD VACCINE INJURY COMPENSATION IN CROATIA}

In the Croatian legal system, children represent a category of persons under special protection of the state and the general duty of all is to preserve the children as the most vulnerable group of persons. ${ }^{69}$ Children have a variety of rights that are inherent to them alone and whose ultimate goal is to protect children when they are growing up. Thus, children's right to health has special importance as it is guaranteed by the Convention on the Rights of the Child and as well as by the Family Act. ${ }^{70}$ From these legal sources, it follows that the state is obliged to provide the best protection of children's needs and interests not only in family relations but also in all socially organized activities such as health policy. ${ }^{71}$ One of the important health policies that aims to protect children and community from diseases is vaccination. As mentioned before, childhood vaccination is considered as one of the best measures to suppress

\footnotetext{
66 Art. 53. e. IDA.

67 The height of monetary compensation is still specified in tolars (previous Slovenian currency) and amount 15 million. Art. 53. b. para 3; art. 53. c. IDA.

68 Art. 53. a. para 4 IDA.

69 Art. 62, 64. Constitution of the Republic of Croatia, Official Gazette of the Republic of Croatia, No. 56/90, 135/97, 113/00, 28/01, 76/10 i 5/14; hereinafter: Constitution.

70 Art. 6., 24. UN General Assembly, Convention on the Rights of the Child, 20 November 1989, United Nations, Treaty Series, vol. 1577, p. 3, available at: http://www.refworld.org/docid/3ae6b38f0.html, accessed 26/03/2018.; hereinafter: CRC; Family Act, Official Gazette of the Republic of Croatia, No. 103/15; hereinafter: FL.

71 Alinčić et al., op. cit. (fn. 3), pp. 9, 223-224,228-229.; Hrabar, op. cit. (fn. 8), pp. 9197.; Alinčić, M., Bakarić Abramović, A., Belajec, V., Dika, M., Hrabar, D., Hrvatin, B., Jakovac-Lozić, D., Korać Graovac, A., Obiteljski zakon - tekst zakona s napomenama, uputama i sudskom praksom, Zagreb, 2013, pp. 101-102.; Šimović, I.: Cijepljenje kao zaštita djetetova prava na zdravlje: obiteljskopravna i ustavnosudska perspektiva, u Bralić, I. (ed.), Cijepljenje $i$ cjepiva, Zagreb, 2016, pp. 49-58.
} 
diseases. $^{72}$ In Croatia, childhood vaccination is mandatory as it is prescribed by Protection of the Population against Communicable Diseases Act and the Ordinance on the Manner of Carrying out Immunization, Seroprophylaxis and Chemoprophylaxis against Communicable Diseases and on the Persons Subject to This Obligation. ${ }^{73}$ The program of continuous immunization of children has been based on mandatory vaccination against ten communicable diseases. ${ }^{74}$ Besides mandatory vaccination that is perceived as a public health intervention against diseases, in Croatia there are also recommended vaccinations whose primary goal is to provide specific protection to people belonging to a specified high-risk population. ${ }^{75}$

However, unlike most European legal systems, there is currently no available program in Croatia, which supports no-fault vaccine injury compensations. Therefore, there is no social justice in Croatian policy regarding childhood vaccine injuries since the burden of health impairment is borne only by a vulnerable minority of adverse events who can seek compensation under the civil law liability. ${ }^{76}$ In other words, the individual injured by a vaccine can seek compensation for health impairment, only through the court proceeding that is usually long and expensive due to complexity of liability determination. The liability of passively legitimate persons (e.g. state, vaccine manufacturer, the physician, the health institutions, or to all of them $)^{77}$ can be determined according to rules of strict and fault liability.

72 Understanding Children's Right to Health, loc. cit.; Dornbusch, H.J., Hadjipanayis, A., del Torso, S. et al. , We strongly support childhood immunization-statement from the European Academy of Pediatrics (EAP), European Journal of Paediatrics 176 (5), pp. 679-680.

73 See Protection of the Population against Communicable Diseases Act, Official Gazette of the Republic of Croatia, No. 79/07, 113/08, 43/09, 22/14-RUSRH; hereinafter: PPCDL.

The minister of health following a proposal of the Croatian National Institute of Public Health enacts childhood vaccination programs. Art. 54, para. 1 The Ordinance on the Manner of Carrying Out Immunization, Seroprophylaxis and Chemoprophylaxis against Communicable Diseases and on the Persons Subject to This Obligation, Official Gazette of the Republic of Croatia, No. 103/13; hereinafter: Ordinance.

74 Croatian Institute for Public Health, Vaccination schedule in 2017, https://www.hzjz.hr/sluzba-epidemiologija-zarazne-bolesti/program-cijepljenja-u-hrvatskoj-u-2017-godini/, accessed on $7 / 06 / 2018$.

75 Tešović, G.: Childhood Vaccinations in Croatia, Periodicum Biologorum, 114 (2), 2012, p. 152.

76 See art. 1049, 1063. Civil Obligation Act, Official Gazette of the Republic of Croatia, No. 35/05, 41/08, 125/11, 78/15; hereinafter: COA.; Campos, L. A., Dórea, J. G., De Sá, N. M.: Judicialization of post-vaccinal adverse events, Revista Bioética, 25 (3), 2017, p. 484.; Nikšić, S.: Understanding Medical Liability, in Beran, R. G. (ur.), Legal and Forensic Medicine, Heidelberg, 2013, p.695.

77 Knol Radoja, K.: Naknada štete prouzročena cijepljenjem, Zbornik Pravnog fakulteta Sveučilišta u Rijeci, 39 (1), 2018, p. 513. 
According to the rule of strict liability, vaccination is determined as a dangerous activity and the one who is performing it could be held liable for injuries that are the outcome of vaccination. ${ }^{78}$ In order to free himself from liability, passively legitimate person has to prove that vaccination as dangerous activity was not the cause of health impairment. ${ }^{79}$ The rule on strict liability was applied in several recent vaccine injury cases. Thus, in decision No. Rev 785/052 of 22 March 2006, the Supreme Court of the Republic of Croatia (hereinafter: SCRC) determined liability of the state for vaccine injury by interpreting vaccination as a dangerous activity prescribed by the state as mandatory for all children. ${ }^{80}$ The same interpretation of vaccination as dangerous activity is highlighted in another SCRC decision (No. Rev 79/07-2 of 10 June 2009) where the Court was deciding on liability of the state regarding childhood vaccine injury caused by the polio vaccine. ${ }^{81}$

The rule of strict liability is also applicable in vaccine injury cases where vaccines are interpreted as defective medical products. ${ }^{82}$ In those cases, the injured party will receive compensation only if it proves the defectiveness of the vaccine, the injury and the causal link between vaccine defect and injury that has occurred after the administration of vaccine. ${ }^{83}$ However, the application of strict liability rules requires from court to seek the existence of a causal link between vaccination and injury that occurred in some short period after the administration of vaccine. That can be time and money consuming for court and parties as causal connection is difficult to prove, especially if health impairment occurs years after the administration of vaccines.

However, if the health impairment was caused by a vaccine that was not defective, the passive legitimate person will be held liable only if his fault is proved according to the general rules on liability. ${ }^{84}$ This means that the court will assign liability for vaccine injury to the passive legitimate person only if vaccine injury is a consequence of his fault, e.g. vaccine injury occurs because of lacks in his behavior - negligence. For example, "physician will be liable for vaccine injury if he does not check the health status of the child before vaccination or

\footnotetext{
78 Art. 1064. COA.

79 Art. 1063 COA.

80 Decision of the Supreme Court of the Republic of Croatia No. Rev 785/05-2 of 22 March 2006.

81 Decision of the Supreme Court of the Republic of Croatia No. Rev 79/07-2 of 10 June 2009.

82 Art. 1073 COA.

83 Art. 1073 para. 8 COA.

84 Baretić, M.: Product Liability in Medicine, in Beran R. (eds), Legal and Forensic Medicine, Berlin, 2003, p. 1805.
} 
does not determine if the vaccine has been tested before being placed on the market"

Regardless the notion that liability for vaccine injury is regulated by the rules of strict and fault liability, on many occasions it is difficult to prove it due to two or more possible causes of vaccine injury. ${ }^{86}$ For example, vaccine injury may be the result of a negligent act or omission by the health care service provider combined with the patient's state of health or the product defectiveness. ${ }^{87}$ Similar standpoint was expressed by the Constitutional Court in decision No. U-III/2729/2015 on 2 December 2015 where the Court had to take into consideration negligence of a physician who administered the vaccine and the existence of inherited genetic defects on the side of the vaccine injured party. ${ }^{8}$ Therefore, the success in proving liability and obtaining vaccine injury compensation mostly depends on the defense strategy of lawyers, which certainly has a negative impact on legal security as proceedings can be unpredictable and result without any compensation. ${ }^{89}$

Since protection of children's health by vaccines is the duty of the state and the vaccination is mandatory as it is considered to be a part of the public health policy, it is especially important that vaccine health impairment is followed by just compensation. As victims of vaccine injury are already suffering from severe or long-term health impairment, they should not be exposed to additional expensive, timing-consuming and stressful litigations. In order to achieve just compensation and to bypass civil litigations, it is necessary to reconsider introduction of no-fault program of compensation.

\section{CONCLUSION}

Childhood vaccination is considered as one of the most important technological advances that protect not only health of children but community health as well. Although, vaccines are extremely safe and harm is rare, some chil-

\footnotetext{
85 Knol Radoja, op. cit. (fn. 77), p. 514.

86 Nikšić, op. cit. (fn. 76), p. 695.

87 Ibid.

88 See Decision of the Constitutional Court of the Republic of Croatia, No. U-III / 2729/2015. of 2 December 2015, http://sljeme.usud.hr/usud/praksaw.nsf/94b579567876f9fcc1256965002d1bf4/c12570d30061ce54c1257f0 f003661af / \$ FILE / U-III-2729-2015.pdf, accessed on 29/03/2018.

89 See Decision of the Supreme Court of the Republic of Croatia Rev-x-572/14-2 of 4 November 2014. It is one of the example how proceeding in case of vaccine health infringement can represent extensive economic burden for claimant, especially as the result of the proceeding is linked to success in proving a wrong due to another person's negligence or deliberate harm.
} 
dren can suffer from serious side effects and experience the long-term health problems. In cases of such health problems, children should be entitled to just compensation for health impairment from the state. Namely, the state cannot protect public health with vaccines and exempt itself from responsibility to undertake necessary legal measures to compensate for individual health damage caused by vaccines. Therefore, if vaccine injures child's health, the costs of the injury should be absorbed by the society as a form of justice.

The notion of justice is highly accepted in most European legal system (e.g. Germany, Italy, France, Slovenia, etc.) and evaluated through no-fault vaccine compensation programs outside the civil litigation. The underlying idea of those programs is that, whenever an individual must suffer a sacrifice for the benefit of the community, the community has a duty to compensate him. Therefore, we may say that European vaccine compensation programs undertake a solidarity function by awarding redress to the unlucky victims of the side effects of a vaccine based on underlying principles of fairness and justice.

In Croatian legal system, there is no solidarity in form of justice and victims of vaccine side effects must seek compensation for health impairment through long and expensive court proceedings. Compensation can be received only if party injured by vaccine proves causal connection between wrong due and vaccination or to prove another person's negligence or deliberate harm. ${ }^{90} \mathrm{To}$ remove the uncertainty of liability proof and to provide more fair approach to injured children, as most vulnerable members of society, de lege ferenda it is necessary for the Croatian legislator to reconsider the introduction of vaccine no-fault compensation program. This program would help children to receive compensation for health impairment regardless of the long and expensive proceedings before court, which are a barrier to expression of social justice in bearing a risk of vaccination side effects. In order to construct an efficient vaccine compensation program, the Croatian legislator should pay special attention on basic elements of the program such as eligibility, standards of proof, modes of compensation, program administration and litigation rights. Regarding eligibility, the legislator needs to prescribe a threshold injury which claimant has to meet in order to claim compensation, as it is in Germany and Slovenia, where health impairment must exceed normal vaccination side effects. ${ }^{91}$ Further, the claimant should be eligible only to seek compensation for health impairment that is caused by mandatory or recommended childhood vaccines,

90 See Decision of the Constitutional Court of the Republic of Croatia, No. U-III / 2729/2015. from December 2, 2015, http://sljeme.usud.hr/usud/praksaw.nsf/94b579567876f9fcc1256965002 d1bf4 / c12570d30061ce54c1257f0f003661af / \$ FILE / U-III-2729-2015.pdf, accessed on 27/03/2018.

$91 \quad$ See supra subtitle 3.1., 3.3. 
as it is in Italy. ${ }^{92}$ To obtain compensation, the claimant should demonstrate reasonable likelihood of causation between health impairment and vaccination with lower level of certainty then in court proceedings under the rules of civil liability. In other words, the compensation program should be "based on a premise that the adverse outcome is not attributable to specific individual but to unavoidable risk associated with vaccines". ${ }^{93}$ The Croatian legislator should also reconsider several modes of compensation similar to German, Italian and Slovenian. ${ }^{94}$ Consequently, children should have the opportunity to obtain several forms of compensation. For example, the compensation program should cover medical treatment as a form of rehabilitation measures, economic rent or compensation for the inability to exercise life ends, sickness benefits for parents etc. Decision on initial eligibility and final compensation should be in the jurisdiction of a state administrative body (e.g. ministry of health) with an option of internal and external review of such decision, as it is the case in Italy and Slovenia. ${ }^{95}$

In the era of budget restrictions, we can expect that vaccine compensation program could represent additional burden on the public budget. To prevent that, the program could initially be modest in size and cover only some range of expenses related to serious, long-term health problems caused by vaccines. To obtain full compensation, the legislator should enable the claimant to seek damages through the courts under civil or product liability cases. Only when the claimant is given an opportunity for full compensation, the state can say that it has successfully integrated a concept of social justice into its legal system.

\section{LITERATURE}

1. Alinčić, M., Hrabar, D., Jakovac-Lozić, D., Korać Graovac, A.: Obiteljsko pravo, Zagreb, 2007.

2. Alinčić, M., et al.: Obiteljski zakon - tekst zakona s napomenama, uputama $i$ sudskom praksom, Zagreb, 2013.

3. Baretić, M.: Product Liability in Medicine, in Beran R. (eds): Legal and Forensic Medicine, Berlin, 2003.

4. Beauchamp, T.L.; Childress, J.F.: Principles of Biomedical Ethics, Oxford, 2001.

\footnotetext{
See supra subtitle 3.2.

3 Looker; Kelly, op. cit. (fn. 28), p. 375.

94 See supra subtitle 3.1.-3.3.

95 See supra subtitle 3.2., 3.3.
} 
5. Bona, M.: Causalità materiale, causalità scientifica e causalità giuridica a confronto: quale ruolo ai consulenti tecnici nell'accertamento del nesso di causa?, in: Bona, M. et al. (eds), Il nesso di causa nel danno alla persona, Milano, 2005.

6. Boncz, I., Sebestyén, A.: Compensation for vaccine injury in Hungary, The Lancet, 367 (9517), 2006.

-DOI: https://doi.org/10.1016/S0140-6736(06)68504-8

7. Brock, D., W.: Priority to the Worst Off in Health-Care Resource Prioritization, in Rhodes, R.; Battin, M. and Silvers, A. (eds.), Medicine and Social Justice, New York, 2002.

8. Campos, L. A., Dórea, J. G., De Sá, N. M.: Judicialization of post-vaccinal adverse events, Revista Bioética, 25 (3), 2017.

-DOI: https://doi.org/10.1590/1983-80422017253205

9. Caranta, R.: Danni da vaccinazione e responsabilità dello Stato, Responsibilità Civile e Previdenz, 63 (1), 1998.

10. Daniels, N.: Justice, Health, and Health care, in Rhodes, R., Battin, M., Silvers, A. (eds.), Medicine and social justice, New York, 2002.

11. Daniels, N.: Just Health Care, Cambridge, 1985.

-DOI: https://doi.org/10.1017/CBO9780511624971

12. Dornbusch, H.J., Hadjipanayis, A., del Torso, S. et al:: We strongly support childhood immunization-statement from the European Academy of Pediatrics (EAP), European Journal of Pediatrics, 176 (5).

13. Evans, G.: Vaccine injury compensation programs worldwide, Vaccine, 17 (3), 1999.

-DOI: https://doi.org/10.1016/S0264-410X(99)00291-1

14. Fine, P., Eames, K., Heymann, D. L.: Herd Immunity: A Rough Guide, Clinical Infectious Diseases, 52 (7), 2011.

-DOI: https://doi.org/10.1093/cid/cir007

15. Hrabar, D.: Prava djece u porodičnim odnosima, Doctoral dissertation, Faculty of Law, Unversity of Zagreb, 1991.

16. Hrabar, D.: Prava djece u obiteljskom zakonodavstvu, u: Hrabar, D. (ed.), Prava djece - multidisciplinarni pristup, Zagreb, 2016.

17. Jefferson, T.: Vaccination and its adverse effects: real or perceived. Society should think about means of linking exposure to potential long-term effect, British Medical Journal, 317 (7152), 1998.

-DOI: https://doi.org/10.1136/bmj.317.7152.159

18. Klarić, P.; Vedriš, M.: Građansko pravo, Zagreb, 2008.

19. Knol Radoja, K.: Naknada štete prouzročena cijepljenjem, Zbornik Pravnog fakulteta Sveučilišta u Rijeci, 39 (1), 2018. 
20. Kompare, N.: Obvezno cepljenje otrok proti nalezljivim boleznim, Pravna praksa, 10, 2015.

21. Kraljić, S.: Obvezno cepljenje v Sloveniji: razkorak med pravom in vsakdanjo prakso? Mandatory vaccination in Slovenia: the gap between law and everday practise?, in Kraljić,, S., Reberšek Gorišek, J., Rijavec, V. (eds.), 27. Posvetovanje Medicina, pravo in družba, (23- 24.3. 2018, Maribor, Slovenija), Sodobni izzivi in dileme: konferenčni zbornik, Maribor, 2018.

22. Lasagna, L.: The Chilling Effect of Product Liability on New Drug Development, in Huber, P., W.; Litan, R., E. (eds.), The Liability Maze: The Impact of Liability Law on Safety and Innovation, Washington, 1991.

23. Looker, C., Kelly, H.: No-fault compensation following adverse events attributed to vaccination: a review of international programmes, Bulletin of the World Health Organization, 89 (5), 2011.

-DOI: https://doi.org/10.2471/BLT.10.081901

24. Lukšić, K.: Pravica ali dolžnost staršev, da odločaju o cepljenju svojih otrok, magistrsko delo, Maribor, 2016.

25. Huber, P., W.; Litan, R. E. (eds.): The Liability Maze, The Impact of Liability Law on Safety and Innovation, Washington, 1991.

26. Mello, M. M.: Rationalizing Vaccine Injury Compensation, Bioethics, 22, (1), 2008.

27. Možina, D.: Odškodninska odgovornost države, Pravni letopis, 2013.

28. Nikšić, S.: Understanding Medical Liability, in Beran, R. G. (ur.), Legal and Forensic Medicine, Heidelberg, 2013.

-DOI: https://doi.org/10.1007/978-3-642-32338-6_53

29. Powers, M., Faden, R.: Social Justice, New York, 2006.

30. Rawls, J.: A Theory of Justice, Cambridge, 1999.

31. Ritz, H. G.: Impfentschädigung, in Deinert, O.; Welti, F. (eds.), Stichwortkommentar Behindertenrecht, Baden-Baden, 2014.

32. Rajneri, E., Borghetti, J. S., Fairgrieve, D., Rott, P.: Remedies for Damage Caused by Vaccines: A Comparative Study of Four European Legal Systems, European Review of Private Law, 26 (1), 2018.

33. Salmon, D. A., et al.: Compulsory vaccination and conscientious or philosophical exemptions: past, present, and future, The Lancet, 367 (9508), 2006.

-DOI: https://doi.org/10.1016/S0140-6736(06)68144-0

34. Statement of the German Standing Committee on Vaccination at the RKI Recommendations of the Standing Committee on Vaccination (STIKO) at the Robert Koch Institute/Effective: August 2015, Epidemiologisches Bulletin, No. 34, 2015.

35. Šimović, I.: Cijepljenje kao zaštita djetetova prava na zdravlje: obiteljskopravna i ustavnosudska perspektiva, in Bralić, I. (ed.), Cijepljenje i cjepiva, Zagreb, 2016. 
36. Tešović, G.: Childhood Vaccinations in Croatia, Periodicum Biologorum, 114 (2), 2012.

37. Tucak, I.: Legal and Ethical Justification of Compensation Regarding Compulsory Vaccination, Law and Politics, 15 (2), 2017.

-DOI: https://doi.org/10.22190/FULP1702145T

38. Verweij, M., Dawson, A.: Children's Health, Public Health, Public Health Ethics, 4 (2), 2011.

-DOI: https://doi.org/10.1093/phe/phr024

39. Walkinshaw, E., Mandatory vaccinations: The international landscape, CMAJ, 183 (16), 2011.

-DOI: https://doi.org/10.1503/cmaj.109-3993

\section{LEGISLATION}

1. Civil Code (Codice civile from 4th April 1942 (in version of 11th January 2018, G.U. 4/2018).

2. Criminal Code (Codice penale from 19th October 1930 (in version of 11th January 2018, G.U. 4/2018).

3. Civil Obligation Act, Official Gazette of the Republic of Croatia, No. 35/05, 41/08, 125/11, 78/15.

4. Constitution of the Republic of Croatia, Official Gazette of the Republic of Croatia, No. 56/90, 135/97, 113/00, 28/01, 76/10 i 5/14.

5. Constitution of WHO as adopted by the International Health Conference, New York, 19 June - 22 July 1946; signed on 22 July 1946 by the representatives of 61 States (Official Records of WHO, no. 2, p. 100) and entered into force on 7 April 1948.

6. Convention on the Rights of the Child, 20 November 1989, United Nations, Treaty Series, vol. 1577, p. 3.

7. Compensation of infringement of irreversible types of outcomes of compulsory vaccination, and transfusion (Decreto Legislativo n. 210 del 25/2/1992, Indennizzo a favore dei soggetti danneggiati da complicanze di tipo irreversibile a causa di vaccinazioni obbligatorie, trasfusioni, G.U. 210/1992; hereinafter: Law $\mathrm{N}^{\circ} 210 / 92$ ).

8. Family Law, Official Gazette of the Republic of Croatia, No. 103/15.

9. Infectious Diseases Act (Zakon o nalezljivih boleznih, Uradni list RD 33/06- officially purified text).

10. The Ordinance on the Manner of Carrying Out Immunization, Seroprophylaxis and Chemoprophylaxis against Communicable Diseases and on the Persons Subject to This Obligation, Official Gazette of the Republic of Croatia, No. 103/13. 
11. Protection against Infection Act (Gesetz zur Verhütung und Bekämpfung von Infektionskrankheiten beim Menschen (Infektionsschutzgesetz)) from 2000. (in version from 17th July 2017, BGB1. I S. 2615).

12. Protection of the Population against Communicable Diseases Act, Official Gazette of the Rebulic of Croatia, No. 79/07, 113/08, 43/09, 22/14-RUSRH.

\section{CASES}

1. Constitutional Court Decision of Republic of Slovenia (Odločba o ugotovitvi, da prva alineja prvega odstavka 22. člena, 4. točka prvega odstavka 57. člena in drugi odstavek 57. člena Zakona o nalezljivih boleznih niso v neskladju z Ustavo, in o ugotovitvi neskladnosti Zakona o nalezljivih boleznih z Ustavo, stran 2906, U-I127/01), Uradni list RS 25/2004. Available at https://www.uradni-list.si/glasilouradni-list-rs/vsebina/2004-01-1089/ ( June 6, 2018.)

2. Decision of the Constitutional Court of the Republic of Croatia, No. U-III / 2729/2015. from December 2, 2015. Available at http://sljeme.usud.hr/usud/ praksaw.nsf/94b579567876f9fcc1256965002 d1bf4 / c12570d30061ce54c1257f0f003661af / \$ FILE / U-III-2729-2015.pdf (March 27, 2018.)

3. Decision of the Supreme Court of the Republic of Croatia No. Rev 785/05-2 of 22 March 2006.

4. Decision of the Supreme Court of the Republic of Croatia No. Rev 79/07-2 of 10 June 2009.

5. Decision of the Supreme Court of the Republic of Croatia Rev.-x-572 / 14-2 from November 4, 2014.

\section{ONLINE SOURCES}

1. Childhood immunisation, https://ec.europa.eu/health/vaccination/childhood_immunisation_en, (June 6, 2018.)

2. Campaign essentials for World Immunization Week 2018, http://www.who.int/ campaigns/immunization-week/2018/campaign-essentials/en/ (March 21, 2018.)

3. Croatian Institute for Public Health, Vaccination schedule in 2017, https://www. hzjz.hr/sluzba

4. epidemiologija-zarazne-bolesti/program-cijepljenja-u-hrvatskoj-u-2017-godini/ (June 7, 2018.)

5. Dispositif de règlement amiable des dommages imputables à des vaccinations obligatoires, Office National d'Indemnisation des Accidents Médicaux, Paris, 2004, http://www.oniam.fr/vaccinations.php, (March 21, 2018.)

6. Kraljić, S., Slovenija spada med države s strogo ureditvijo, 2018, https://www.vecer. com/slovenija-spada-med-drzave-s-strogo-ureditvijo-6382626 (June 7, 2018.) 
7. Public Health Ethics, https://plato.stanford.edu/entries/publichealth-ethics/\#Pat, (March 18, 2018.)

8. Understanding Children's Right to Health, https://www.humanium.org/en/fundamental-rights-2/health/ (January 1, 2018.)

9. Vaccine-preventable diseases, https://ecdc.europa.eu/en/immunisation-vaccines/ facts/vaccine-preventable-diseases (June 6, 2018.)

10. Vaccine Side Effects and Adverse Events, https://www.historyofvaccines.org/ content/articles/vaccine-side-effects-and-adverse-events, (January 1, 2018.) 
